\title{
Parasites of the Mutton Snapper Lutjanus analis (Perciformes: Lutjanidae) in Alagoas, Brazil
}

\author{
Parasitas de Cioba Lutjanus analis (Perciformes: Lutjanidae) em Alagoas, Brasil \\ Margarida Hermida ${ }^{1,2}$; Bruno Ferreira Lyra Carvalho ${ }^{3}$; Cristina Cruz ${ }^{1,2}$; Aurélia Saraiva ${ }^{1,2 *}$ \\ ${ }^{1}$ Departamento de Biologia, Faculdade de Ciências - FC, Universidade do Porto - UP, Porto, Portugal \\ ${ }^{2}$ Centro Interdisciplinar de Investigação Marinha e Ambiental - CIIMAR, Universidade do Porto - UF, Porto, Portugal \\ ${ }^{3}$ Projeto de Cooperação Técnica FAO/MPA “Por um Desenvolvimento Sustentável da Aquicultura”, \\ Ministério da Pesca e Aquicultura - MPA, Brasília, DF, Brazil
}

Received September 9, 2013

Accepted December 17, 2013

\begin{abstract}
A parasitological survey was carried out on a sample of sixty mutton snappers (Lutjanus analis) that were caught on the coast of Alagoas, northeastern Brazil. The parasite diversity and infection levels were low. The ectoparasite Rocinela signata Schioedte \& Meinert, 1879 (Isopoda: Aegidae), and larvae of two endoparasites, Trypanorhyncha gen. sp. and Hysterothylacium sp. (Nematoda: Anisakidae), were detected. The significance of these parasites is discussed in the context of their transmission pathways and potential impact.
\end{abstract}

Keywords: Fish, Rocinela, Trypanorhyncha, Hysterothylacium.

\section{Resumo}

Um estudo parasitológico foi realizado em 60 exemplares de cioba, Lutjanus analis, capturados ao largo de Alagoas, no Nordeste do Brasil. A diversidade e níveis de infecção parasitária foram baixos. Foram detectados o ectoparasito Rocinela signata Schioedte \& Meinert, 1879 (Isopoda: Aegidae) e dois endoparasitos, larvas de Trypanorhyncha gen. sp. e larvas de Hysterothylacium sp. (Nematoda: Anisakidae). O significado desses parasitos é discutido no âmbito das suas vias de transmissão e potencial impacto.

Palavras-chave: Peixe, Rocinela, Trypanorhyncha, Hysterothylacium.

\section{Introduction}

The mutton snapper, Lutjanus analis (Cuvier, 1828), is a commercially important perciform fish of the Lutjanidae family that occurs in the western Atlantic from $36^{\circ} \mathrm{N}$ to $28^{\circ} \mathrm{S}$ (FROESE; PAULY, 2011). It inhabits coastal areas associated with reefs or islands. Juveniles are usually found in estuaries or close to shore, among sea grasses and coral reefs, whereas adults tend to occur on the outer shelf, mostly in the 20-80 m depth stratum (CARVALHO-FILHO, 1999; FRÉDOU; FERREIRA, 2005). Mutton snappers are carnivorous, feeding primarily on crustaceans, fish and molluscs (MENEZES; FIGUEIREDO, 1980).

The fishing industry in northeastern Brazil is characterized by predominance of artisanal fisheries (CASTELLO, 2010). Reef-associated fish represent almost half of the total catch by weight, and the mutton snapper is one of the main targets of

\footnotetext{
*Corresponding author: Aurélia Saraiva

Departamento de Biologia, Faculdade de Ciências - FC,

Universidade do Porto - UP, Rua do Campo Alegre, Edifício FC4,

Código Postal 4169-007, Porto, Portugal

e-mail: amsaraiv@fc.up.pt

Financial support: European Regional Development Fund (ERDF) e

FCT (Foundation for Science and Technology).
}

this fishery (FRÉDOU; FERREIRA, 2005). Because of its high commercial value and the current overexploitation of its natural stocks, $L$. analis has been identified as one of the best prospects for aquaculture (WATANABE et al., 1998), and preliminary studies in floating net cages have suggested that production of this fish is viable (BENETTI et al., 2002).

Despite its commercial importance in northeastern Brazil, few parasitological studies have so far been conducted on L. analis. Palm (1997) detected a single specimen of Grillotia sp. (Cestoda: Trypanorhyncha) from the body cavity of a mutton snapper, but specific identification was not possible. Moreira (1977) detected the isopod Rocinela signata (Isopoda: Aegidae) on the gills of L. analis off the state of Santa Catarina, in southern Brazil. Elsewhere, the monogenean Haliotrema sp. has been detected in L. analis in Venezuela (FUENTES et al., 2009), and nematodes Capillaria sp. and Contracaecum sp. in Colombia (CORTÉS et al., 2009).

The main purpose of the present study was to assess the parasite fauna of this important commercial species in Alagoas, northeastern Brazil, and to evaluate occurrences of parasites that might constitute potential threats to its production in floatingcage aquaculture. 


\section{Materials and Methods}

A total of 60 mutton snappers (L. analis) were caught by fishermen between December 2010 and March 2011 in various localities off the coast of Alagoas. Onshore, the fish were killed by means of thermal shock and were transported in ice boxes to the laboratory. They were weighed and measured, and their sex was determined through visual analysis of the gonads. Fulton's condition factor was determined using the equation $\mathrm{K}=100 \mathrm{~W} / \mathrm{L}^{3}$ where $\mathrm{W}$ = whole body wet weight in grams and $\mathrm{L}=$ total length in $\mathrm{cm}$ (FROESE, 2006). Parasitological analyses were carried out using routine laboratory procedures. Macroscopic observation of the tegument, fins, nasal orifices and buccal cavity was followed by stereomicroscopic observation of the separate gill arches, heart, spleen, swimbladder, digestive tract, liver, gallbladder and kidney. Parasites that were detected were isolated and preserved in alcohol $(70 \% \mathrm{v} / \mathrm{v})$. All the parasites were cleared using increasing concentrations of glycerol and were observed under an optical microscope. Cestodes were also stained in carmine prior to optical microscope observation.

Prevalence, mean intensity and mean abundance were determined as described by Bush et al. (1997). Statistical analyses were carried out using IBM Statistics software. Correlations between fish length (total length) and parasite species abundance were analyzed using the Spearman rank correlation. For all tests, statistical significance was accepted when $\mathrm{p}<0.05$.

\section{Results}

In the sample of 60 mutton snappers ( $L$. analis) caught off Alagoas, the mean weight of the fish was $1496.7 \pm 828.3 \mathrm{~g}$ (range: 650-4800 g) and the total length was $45.6 \pm 6.1 \mathrm{~cm}$ (range: $38-$ $66 \mathrm{~cm}$ ). Females constituted $51.7 \%$ of the sample, whereas the remaining $48.3 \%$ were males. The mean condition factor was $1.480 \pm 0.307$ (range: 0.900-2.400).

The parasites detected in the sampled mutton snappers were Trypanorhyncha gen. sp. larvae (Cestoda), which were encapsulated in the visceral cavity; Hysterothylacium sp. larvae (Nematoda: Anisakidae) in the stomach lumen; and the ectoparasite Rocinela signata Schioedte \& Meinert, 1879 (Isopoda: Aegidae), located in the gill chamber. The infection levels are presented in Table 1.

The condition of the trypanorhynch plerocercoids found did not allow their specific identification; however, two well- developed bothrids and four tentacles were observed in all these specimens. Likewise, it was not possible to identify the species of Hysterothylacium sp. larvae. The nematodes detected were L3 larvae, showing their characteristic perforator tooth. The two isopods detected measured 3 and $4 \mathrm{~mm}$ and they clearly exhibited the morphological features of $R$. signata, in particular the typical inverted W-shaped pigmented figure on the pleotelson (Brusca; Iverson 1985).

A significant positive correlation was found between the total length of the fish and Trypanorhyncha gen. sp. larval abundance $(\mathrm{r}=0.358 ; \mathrm{p}=0.005)$

\section{Discussion}

Both the parasite diversity and the infection levels detected were unexpectedly low. Fish size and feeding habits tend to be good predictors of the species richness of parasite assemblages (LUQUE et al., 2004). In particular, carnivorous fishes tend to be associated with greater diversity of endoparasites, which they acquire from their prey (LUQUE et al., 2004). The low diversity detected in this study could be related to the limited sampling period analyzed.

The aegid isopod $R$. signata occurs in the eastern Pacific and western Atlantic from Florida to Brazil at depths of up to $68 \mathrm{~m}$ (BRUCE, 2009). It is an ectoparasite commonly found in fishes in northeastern Brazil (CARVALHO-SOUSA et al., 2009), and has previously been detected in L. analis (MOREIRA, 1977). Aegids are temporary parasites that attach to their hosts and suck blood, and they usually have very low host specificity; in fact, $R$. signata is known to attack humans (GARZÓN-FERREIRA, 1990). These isopods often have a negative impact on fish, through stunting growth and causing wounds that are liable to lead to secondary infection (BUNKLEY-WILLIAMS; WILLIAMS, 1998), and they can be particularly detrimental to fish in floating net cages, where they cannot be avoided. It is conceivable that they might also cause respiratory problems when they are located on the gills, as was the case in this study, especially due to their large size.

A trypanorhynch larval specimen had previously been detected by Palm (1997) in a mutton snapper from Brazil. The occurrences of trypanorhynch plerocercoids seem to indicate that the mutton snapper serves as an intermediate host for these cestodes, for which elasmobranchs are their definitive hosts. These parasites may have been acquired through consumption of crustaceans such as

Table 1. Infection levels of parasites in Lutjanus analis with mean intensity and abundance \pm standard deviation are followed by range in parenthesis, in Alagoas, Brazil.

\begin{tabular}{|c|c|c|c|}
\hline & Prevalence (\%) & Mean Intensity \pm SD $(\min -\max )$ & Mean Abundance \pm SD (min-max) \\
\hline Trypanorhyncha gen. sp. & 10.0 & $\begin{array}{c}1.33 \pm 0.52 \\
(1-2)\end{array}$ & $\begin{array}{c}0.13 \pm 0.43 \\
(0-2)\end{array}$ \\
\hline Hysterothylacium sp. & 3.3 & $\begin{array}{c}3.00 \pm 2.83 \\
(1-5)\end{array}$ & $\begin{array}{c}0.10 \pm 0.66 \\
(0-5)\end{array}$ \\
\hline Rocinela signata & 3.3 & $\begin{array}{c}1.00 \pm 0.00 \\
\text { (1) }\end{array}$ & $\begin{array}{c}0.03 \pm 0.18 \\
(0-1)\end{array}$ \\
\hline Total Parasites & 13.3 & $\begin{array}{c}2.00 \pm 1.60 \\
(1-5)\end{array}$ & $\begin{array}{c}0.27 \pm 0.88 \\
(0-5)\end{array}$ \\
\hline
\end{tabular}


harpacticoid copepods (MARCOGLIESE, 2002). The abundance of Trypanorhyncha gen. sp. larvae was positively correlated with fish size (total length), which suggests that they tend to accumulate in the fish with increasing host size. This is a common pattern for trophically transmitted endoparasites' development stages, which persist in the intermediate host for long periods of time (e.g. HERMIDA et al., 2012). However, it could also be related to changes in the depth range and feeding habits among older mutton snappers.

The anisakid nematode Hysterothylacium sp. had not been previously detected in L. analis; however, it is a widespread marine fish parasite that has often been detected in fish in Brazil (KNOFF et al., 2012), including from the northeastern region (SAAD; LUQUE, 2009).

In conclusion, low parasite diversity and infection levels were detected in mutton snappers ( $L$. analis) of Alagoas, and the isopod Rocinela signata presents the greatest potential threat to development of marine cage cultivation of $L$. analis.

\section{Acknowledgements}

This research was partially supported by the European Regional Development Fund (ERDF) through the COMPETE Operational Competitiveness Programme and by national funds through FCT (Foundation for Science and Technology), under the project "PEst-C/MAR/LA0015/2011".

\section{References}

Benetti DD, Matera JA, Stevens OM, Alarcón JF, Feeley MW, Rotman FJ, et al. Growth, survival, and feed conversion rates of hatchery-reared mutton snapper Lutjanus analis cultured in floating net cages. J World Aquacult Soc 2002; 33(3): 349-357. http://dx.doi. org/10.1111/j.1749-7345.2002.tb00511.x

Bruce NL. The Marine Fauna of New Zealand: Isopoda, Aegidae (Crustacea). NIWA Biodiversity Memoir 2009; 122: 1-252.

Brusca RC, Iverson EW. A Guide to the Marine Isopod Crustacea of Pacific Costa Rica. Rev Biol Trop 1985; 33(S1): 1-77.

Bunkley-Williams L, Williams EH. Isopods associated with fishes: a synopsis and corrections. J Parasitol 1998; 84(5): 893-896. http://dx.doi. org/10.2307/3284615

Bush AO, Lafferty KD, Lotz JM, Shostak AW. Parasitology meets ecology on its own terms: Margolis et al. revisited. J Parasitol 1997; 83(4): 575583. http://dx.doi.org/10.2307/3284227

Carvalho-Filho A. Peixes: costa brasileira. 3. ed. São Paulo: Editora Melro; 1999.

Carvalho-Sousa GF, Neto JRS, Aleluia FT, Nascimento IA, BrowneRibeiro H, Santos RC, et al. Occurrence of isopods ectoparasites in marine fish on the Cotegipe Bay, north-eastern Brazil. Mar Biodivers Rec 2009; 2: e160. http://dx.doi.org/10.1017/S1755267209990844

Castello JP. O futuro da Pesca e Aquicultura marinha no Brasil: A pesca Costeira. Cienc Cult 2010; 62(3): 32-35.
Cortés J, Valbuena J, Manrique G. Nemátodos parásitos de Lutjanus synagris (Linneaus, 1758) y Lutjanus analis (Cuvier, 1828) (Perciformes, Lutjanidae) en las zonas de Santa Marta y Neguanje, Caribe Colombiano. Rev Med Vet Zoot 2009; 56(1): 23-31.

Frédou T, Ferreira BP. Bathymetric trends of Northeastern Brazilian snappers (Pisces, Lutjanidae): Implications for the reef fishery dynamic. BrazArch Biol Technol 2005; 48(5): 787-800. http://dx.doi.org/10.1590/ S1516-89132005000600015

Froese R. Cube law, condition factor and weight-length relationships: history, meta-analysis and recommendations. $J$ Appl Ichthyol 2006; 22(4): 241-253. http://dx.doi.org/10.1111/j.14390426.2006.00805.x

Froese R, Pauly D. FishBase. version (10/2011). Available from: www. fishbase.org.

Fuentes JL, Arias IS, Guerra YMM, Martínez OLC. Monogeneos parásitos de peces de la laguna Las Marites, Isla de Margarita, Venezuela. INCI 2009; 34(7): 507-513.

Garzón-Ferreira J. An isopod, Rocinela signata (Crustacea: Isopoda: Aegidae), that attacks humans. B Mar Sci 1990; 46(3): 813-815.

Hermida M, Mota R, Pacheco CC, Santos CL, Cruz C, Saraiva A, et al. Infection levels and diversity of anisakid nematodes in blackspot seabream, Pagellus bogaraveo, from Portuguese waters. Parasitol Res 2012; 110(5): 1919-1928. http://dx.doi.org/10.1007/s00436-0112718-4

Knoff M, Felizardo NN, Iñiguez AM, Maldonado A Jr, Torres EJL, Pinto $\mathrm{RM}$, et al. Genetic and morphological characterisation of a new species of the genus Hysterothylacium (Nematoda) from Paralichthys isosceles Jordan, 1890 (Pisces: Teleostei) of the Neotropical Region, state of Rio de Janeiro, Brazil. Mem Inst Oswaldo Cruz 2012; 107(2): 186-193. http:// dx.doi.org/10.1590/S0074-02762012000200006

Luque JK, Mouillot D, Poulin R. Parasite biodiversity and its determinants in coastal marine teleost fishes of Brazil. Parasitology 2004; 128(Pt6): 671682. http://dx.doi.org/10.1017/S0031182004005050

Marcogliese DJ. Food webs and the transmission of parasites to marine fish. Parasitology 2002; 124: S83-S99. http://dx.doi.org/10.1017/ S003118200200149X

Menezes NA, Figueiredo JL. Manual de peixes marinhos do sudeste do Brasil - IV Teleostei (3). São Paulo: Museu de Zoologia da Universidade de São Paulo; 1980. 96 p.

Moreira PS. Occurrence and ecological notes on Rocinela signata (Isopoda, Flabellifera) off Brazil. Bol Inst Oceanogr 1977; 26(2): 293-301. http://dx.doi.org/10.1590/S0373-55241977000200007

Palm HW. Trypanorhynch cestodes of commercial fishes from Northeast Brazilian coastal waters. Mem Inst Oswaldo Cruz 1997; 92(1): 69-79. http://dx.doi.org/10.1590/S0074-02761997000100014

Saad CDR, Luque JL. Larvas de Anisakidae na musculatura do pargo, Pagrus pagrus, no Estado do Rio de Janeiro, Brasil. Rev Bras Parasitol Vet 2009; 18(S1): 71-73. http://dx.doi.org/10.4322/rbpv.018e1014

Watanabe W, Ellis EP, Ellis SC, Chaves J, Manfredi C, Hagood RW, et al. Artificial propagation of mutton snapper Lutjanus analis, a new candidate marine fish species for aquaculture. J World Aquacult Soc 1998; 29(2): 176-187. http://dx.doi.org/10.1111/j.1749-7345.1998. tb00977.x 